\title{
弾塑性時刻歴応答を考慮した鋼構造建物の設計問題のための 部分的感度情報を用いた最適設計法 \\ OPTIMUM DESIGN METHODS FOR STEEL FRAMES CONSIDERING TRANSIENT DYNAMIC ELASTO-PLASTIC RESPONSES USING PARTLY AVAILABLE SENSITIVITY INFORMATION
}

\author{
山川誠*, 大崎＼cjkstart純**, 満田衛資*** \\ Makoto YAMAKAWA, Makoto OHSAKI and Eisuke MITSUDA
}

\begin{abstract}
Design problems with transient dynamic elasto-plastic analysis exhibit noisy and nonsmooth responses with respect to their design parameters. This leads to situations in which some derivatives may be inaccurate and/or computationally expensive to obtain, whereas others may be readily available. For such problems, derivative-free approaches seem to be more appropriate than conventional derivative-based methods because some derivatives do not exist and/or are noisy. High cost for derivative evaluation is also frequently encountered in real-world design problems. This paper presents a new optimization method which is essentially derivative-free. However, the proposed method can reflect the geometry of some smooth and inexpensive response functions. This enables enhancement of the derivative-free method by including the derivative information on some constraints. The approach can be interpreted as a practical compromise between derivative-based and derivative-free methods. Furthermore, the proposed method can also be interpreted as a meta-modeling framework, ensuring global convergence in nonsmooth optimization. The efficiency of the proposed method is studied through a numerical example of steel frame with transient analysis. The numerical result illustrates that the proposed method finds better solutions than typical derivative-based and derivative-free methods and shows reasonable convergence in all cases.
\end{abstract}

Keywords : Transient response analysis, Structural optimization, Design sensitivity, Direct search method, Buckling restrained brace 時刻歷応答解析, 構造最適化, 設計感度, 直接探索法, 座屈拘束ブレース

1. はじめに

断層近傍・長周期地震動といった建築基準法のレベルを大きく上 回る極大地震が構造物の挙動に及ぼす危険性が指摘 ${ }^{1)}$ れる一方で, 制振構造のデバイス開発に代表される建築構造の高機能化・多機能 化により設計上の自由度は拡大しており, これまで以上に高度な工 学的判断が要請されるようになっている.このような要請に応えう る合理的な数理的設計法の確立, および問題構造の明確化は意義あ るものと言える.

建築構造の耐震設計においては地震時応答が設計条件として与え られる. 応答の線形性・定常性を仮定しないため, 大振幅速度パル スを含む内陸直下型地震動, 多数回の繰返し振動を受けるような長 周期地震動等, 地震動の種類に関わらず時刻歴応答解析は適用可能 であり, 調整すべきパラメータも他の方法に比べると少ないため,
超高層骨組の実務設計では時刻歴応答の最大值による検討が主流で ある例えば2)，実務設計との整合性を考えた場合に制約条件あるいは 目的関数に弾塑性時刻歴応答を含むような最適化問題に耐震設計の 設計問題を定式化することは自然である。この種の問題は機械・航 空の構造設計でも現れ，構造最適化として多くの研究・調查がなさ れている(3) 4) . ここで, 弾塑性時刻歴応答は以下の特徵を持つ.

1) 継続時間中の最大応答值を対象とする場合, 設計パラメータ の変化に対する最大応答值の感度係数は不連続となる.

2) 弾塑性等の材料非線形性を Bi-linear 型のような折れ線状に与 えた場合, 設計パラメータの変化に対する応答值の感度係数 は不連続となる。

すなわち，弾塑性時刻歴応答を設計条件として含む関数は連続微分 不可能な非平滑関数である。このような問題に対して, 設計感度に
${ }^{*}$ 京都大学大学院工学研究科建築学専攻 助教 $\cdot$ 博士 $($ 工学 $)$

** 広島大学大学院工学研究科建築学専攻 教授 $\cdot$ 博士 (工学 $)$ *** 満田衛資構造計画研究所 工修
Assist. Prof., Dept. of Architecture and Architectural Engineering, Graduate School of Engineering, Kyoto University, Dr. Eng.

Prof., Dept. of Architecture, Graduate School of Engineering, Hiroshima University, Dr. Eng. Mitsuda Structural Consultants, M. Eng. 
基づく標準的な非線形計画法は一次の最適性条件（必要条件）を満 たす点への大域的収束性を保証していない例えは6). 以上より，建築 構造の分野に限らず時刻歷応答を考慮した設計問題は標準的な非線 形計画法の適用が難しい問題として知られている. さらに建築構造 の耐震設計への適用を考えた場合には，以下の要件が加えられる.

3) 入力波形に含まれる雑音成分や周波数成分の偏りが関数值お よび設計感度に影響を与えるため, その忘答值は局所的にも 非凸性・非単調性の強い関数となる。

例えば，弾性一自由度の場合には変位応答スペクトルの底，あるい はある值以下となる部分を探す問題に上記は対応する. 日本建築セ ンター模擬波BCJ-L2 $2^{7}$ を例として減衰定数 $h=2 \%$ の変位応答スペ クトルを描くと図1に示すようになり，3)で述べたように応答関数 には局所的な底が多数存在することがわかる.

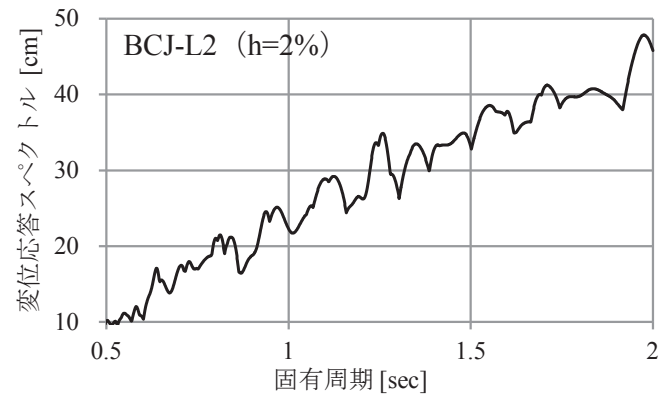

図 1 変位応答スペクトル (BCJ-L2)

このような状況でも差分計算による感度近似と標準的な非線形計画 法を組み合わせることは選択肢の一つである，実際，十分な大きさ の差分幅を与えれば応答值の雑音成分・数值誤差を微分值から除去 することができる．ただし，適切な差分幅を決定することは難しく， 最適性条件と収束性を結びつけることができないという理論的妥当 性の欠如に変わりはない。

非平滑性・雑音性を含む最適化問題に対してderivative-freeな方法 の有効性が近年再注目されている ${ }^{8)}$. そのような方法の一つとして 直接探索法が知られている. 直接探索法は古典的な最適化法である が，感度情報を用いない最適化法としての現代的な再解釈がなされ ている ${ }^{9)}$. 直接探索法は感度解析における諸問題の影響を受けない 方法であり, さらに応答の非平滑性が強く雑音成分も含まれるよう な条件の良くない問題に対しても良い解が求められることが報告さ れている例えば10)。さらにある種の条件を満たせば，非平滑あるいは 不連続な関数を含む最適化問題に対しても最適性条件 (一次の必要 条件）を満たす点への大域的な収束性が保証されるという特徵を持 $\supset^{11,12)}$.

耐震設計への適用を考えた場合には, 雑音性を持つ非平滑な条件 とともに連続微分可能な扱い易い設計条件も同時に含んでいること が一般的と考えられる. 感度情報を利用可能な制約条件については 感度情報を用いることが合理的である．以上のような背景のもとで， 本論では, 連続微分不可能な関数と可能な関数が混在する問題に対 して，大域的収束性が保証され，かつ良好な探索結果を示寸方法を 提案する.

本論で用いる記法について，以下に簡単にまとめる。ベクトルの
成分は下付き添字を用いて $x_{1}, x_{2}, \cdots, x_{n}$ のように表し, ベクトルの列 は上付き添字を用いて $\mathbf{x}^{1}, \mathbf{x}^{2}, \cdots, \mathbf{x}^{n}$ と表す. 列の項数が無限大である 点列 $\left\{a_{n}\right\}_{n=1}^{\infty}=\left\{a_{1}, a_{2}, \cdots\right\}$ を無限列と呼び, 誤解が生じない場合には 簡潔に $\left\{a_{n}\right\}$ と表す. $\left\{a_{n}\right\}$ から無限個の項をとりだした（あるいは無 限個の項を間引いた） $\left\{a_{k(j)}\right\}_{j=1}^{\infty}=\left\{a_{k(1)}, a_{k(2)}, \cdots\right\}$ も無限列であり $\left\{a_{n}\right\}$ の部分列と呼ぶ.ここで， $k(j) \in \mathbb{N}(j=1,2, \cdots)$ かつ $k(1)<k(2)<\cdots$ とする. $\left\{a_{n}\right\}$ の部分列 $\left\{a_{k(j)}\right\}_{j=1}^{\infty}$ の添字集合を $K=\{k(1), k(2), \cdots\}$ と 表すとき, 部分列 $\left\{a_{k(j)}\right\}_{j=1}^{\infty}$ を $\left\{a_{k}\right\}_{k \in K}$, 部分列の極限 $\lim _{j \rightarrow \infty} a_{k(j)}$ を $\lim _{k \in K} a_{k}$ とそれぞれ簡潔に表す.

\section{2. 直接探索法}

\section{1. 対象問題}

本節では, まず, 対象とする最適化問題を定式化する. 実数変数 のベクトルを $\mathbf{x}=\left(x_{1}, \ldots, x_{n}\right)^{T}$, 局所的に変化量が無限大とならない 局所Lipschitz連続 (Appendix A参照) な関数を $f_{i}(\mathbf{x}) \quad\left(i=1, \ldots, I_{1}\right)$ と し，目的関数 $f_{0}(\mathbf{x})$ をそれらの関数の最大值とする．また，平滑な 連続関数（連続微分可能関数）を $g_{i}(\mathbf{x}) \quad(i=1, \ldots, I)$, 局所Lipschitz 連続な関数を $g_{i}(\mathbf{x}) \quad\left(i=I+1, \ldots, I_{2}\right)$ とする.さらに, $\mathbf{A} を m \times n$ 行 列, $\mathbf{b}=\left(b_{1}, \ldots, b_{m}\right)^{T}$ とし, 次の最適化問題を定義する.

$$
\left.\begin{array}{ll}
\underset{\mathbf{x}}{\operatorname{minimize}} & f_{0}(\mathbf{x}):=\max \left\{f_{i}(\mathbf{x}) ; i=1, \ldots, I_{1}\right\} \\
\text { subject to } & \mathbf{A x} \leq \mathbf{b}, \\
& g_{i}(\mathbf{x}) \leq 0 \quad\left(i=1, \ldots, I, I+1, \ldots, I_{2}\right)
\end{array}\right\}
$$

ここで，次の仮定をおく，

[仮定1］ $f_{i}(\mathbf{x}) \quad\left(i=1, \ldots, I_{1}\right)$ および $g_{i}(\mathbf{x}) \quad\left(i=I+1, \ldots, I_{2}\right)$ に比心゙ て,$g_{i}(\mathbf{x}) \quad(i=1, \ldots, I)$ の評価に要する計算コストは十 分小さい.

後に $f_{i}(\mathbf{x}) \quad\left(i=1, \ldots, I_{1}\right)$ または $g_{i}(\mathbf{x}) \quad\left(i=I+1, \ldots, I_{2}\right)$ に弾塑性時刻 歴応答解析についての関数を, $g_{i}(\mathbf{x}) \quad(i=1, \ldots, I)$ に静的荷重作用時 の弾性応答解析についての関数を対応させる. 一般に, 前者は後者 に比べて十分大きい計算時間を要するのでは仮定 1 は妥当性を持つ と言える

パラメータ $\mu>0$ を用いて問題(1)を

$$
\left.\begin{array}{ll}
\underset{\mathbf{x}}{\operatorname{minimize}} & f(\mathbf{x}):=f_{0}(\mathbf{x})+\mu \sum_{i=I+1}^{I_{2}} \max \left\{0, g_{i}(\mathbf{x})\right\} \\
\text { subject to } & \mathbf{x} \in \Omega
\end{array}\right\}
$$

と書き換える．ここで， $\Omega=\left\{\mathbf{x} \mid \mathbf{A x} \leq \mathbf{b}, g_{i}(\mathbf{x}) \leq 0 ; i=1, \ldots, I\right\}$ とし， 連 続微分可能な制約条件 $\mathbf{A x} \leq \mathbf{b}$ 及び $g_{i}(\mathbf{x}) \leq 0(i=1, \ldots, I)$ を満たす $\mathbf{x}$ の集合とする.このような定式化は正確なペナルティ関数法として 知られており ${ }^{13)}, \mu>0$ を十分大きく与えれば問題(1)と問題(2)の解 は一致する.さらに次の仮定をおく.

[仮定2] ある初期解 $\mathbf{x}^{0} \in \Omega$ に対する関数 $f(\mathbf{x})$ のレベル集合 $\left\{\mathbf{x} \in \Omega: f(\mathbf{x}) \leq f\left(\mathbf{x}^{0}\right)\right\}$ は有界閉集合である.

通常，建築構造の設計問題は仮定2を満たすので，仮定2は形式的な ものである。

\section{2. 直接探索法}

直接探索法（Directional Direct Search Method，以下DSMと記す） の基本的なアルゴリズムを図2に示す。Algorithm 1 において, $\rho\left(\mathbf{x}^{k}, \Delta_{k}\right)$ はforcing functionと呼ばれ，例えば定数 $\alpha>0$ に対し 
$\alpha \max \left\{1, f\left(\mathbf{x}^{k}\right) \mid\right\}\left(\Delta_{k}\right)^{2}$ と与える. 探索点の受け入れ条件に forcing functionを用いることは「十分な降下条件 (sufficient decrease condition)」と呼ばれ, Algorithm 1の収束性を保証することができる （Appendix B参照） .

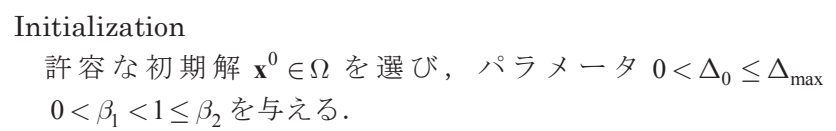

For $k=0,1,2, \cdots$

1. Search step : $f(\mathbf{x})<f\left(\mathbf{x}^{k}\right)-\rho\left(\mathbf{x}^{k}, \Delta_{k}\right)$ を満たす $\mathbf{x} \in \Omega$ を探索 する。もしそのような $\mathbf{x}$ が見つかれば $\mathbf{x}^{k+1}=\mathbf{x}$ と与え，第 $k$ 回目の繰り返しは「成功」と宣言する.

2. Poll step：探索方向集合 $D_{k} \subset \mathbb{R}^{n}$ を選び，探索点集合 $P_{k}=\left\{\mathbf{x}^{k}+\Delta_{k} \mathbf{p} \mid \mathbf{p} \in D_{k}\right\} \cap \Omega$ に含まれる点で関数 $f$ を評価す る. $f(\mathbf{x})<f\left(\mathbf{x}^{k}\right)-\rho\left(\mathbf{x}^{k}, \Delta_{k}\right)$ を満たす探索点 $\mathbf{x} \in P_{k}$ が見つか れば， $\mathbf{x}^{k+1}=\mathbf{x}$ と与え，第 $k$ 回目の繰り返しは「成功」と宣 言する. そのような探索点が見つからなければ, $\mathbf{x}^{k+1}=\mathbf{x}^{k}$ と 与える.

3. Step size parameter update：もし「成功」と宣言されていれば ステップサイズを $\Delta_{k+1}=\max \left\{\Delta_{k}, \min \left\{\Delta_{\max }, \beta_{2} \Delta_{k}\right\}\right\}$ と拡大 させ，「成功」と宣言されていなければ $\Delta_{k+1}=\beta_{1} \Delta_{k}$ と縮小 させる.

\section{図 2 Algorithm 1（直接探索法）}

Algorithm 1 の Search step において「成功」と宣言された場合, Poll step をスキップして Step size parameter update に進むことが一般的で あるが ${ }^{8)}$ ，後述する理由により本論ではこのようなスキップは行わ ず Poll step を毎回行う。ここで，最適性条件 (Appendix C 参照) を満たす点への収束性と Algorithm 1 を結びつけるためには, 探索 方向集合 $D_{k}$ がある条件を満たす必要がある。この条件は次のよう に表せる (Appendix D 参照).

条件1：ある集合 $S$ に含まれる任意の単位ベクトル $\mathbf{v}$ に対して， $\mathbf{v}$ との距離が任意の正の微小值以下に確率1で収束するようなべク トルの列が $\left\{D_{k}\right\}$ の要素に含まれる.

Algorithm 1により生成される点列が $\hat{\mathbf{x}}$ に収束するとき，集合 $S$ は $\hat{\mathbf{x}}$ における $\Omega$ の接錐 $T_{\Omega}(\hat{\mathbf{x}})$ を含む必要がある。既往の方法 $\left.{ }^{11} 12\right)$ では, 単位超球面を集合 $S$ に与え，単位超球面上でランダムに方向ベク トルの集合 $D_{k}$ を生成するアプローチをとっている。この場合，条 件1を満たすことを示すことができる.このような $\mathbf{x}^{k}$ のまわりの単 位超球面上で方向ベクトルをランダム生成する場合の概念図を図 3 に示す。なお，灰色の線で塗られた領域は集合 $\Omega$, 矢印はランダ ム生成された単位方向ベクトルの集合 $D_{k}$ をそれぞれ表す.

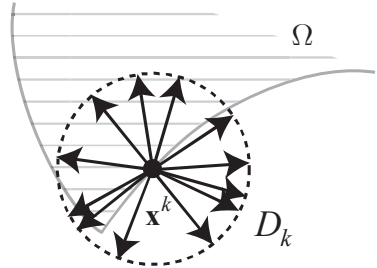

図 3 単位超球面上での方向ベクトルのランダム生成

\section{3. 最適性条件を満たす探索方向集合の生成}

簡単のために $\Omega=\left\{\mathbf{x} \mid g_{i}(\mathbf{x}) \leq 0 ; i=1, \ldots, I\right\}$ の場合を考える. $\varepsilon>0$ ， $\mathbf{x} \in \Omega$ における集合 $\Omega$ の $\varepsilon$-線形化錐を

$$
C_{\Omega}(\mathbf{x}, \varepsilon)=\left\{\mathbf{d} \in \mathbb{R}^{n} \mid \nabla g_{i}(\mathbf{x})^{T} \mathbf{d} \leq 0, i \in \mathcal{A}(\mathbf{x} ; \varepsilon)\right\}
$$

と定義する，ここで，

$$
\mathcal{A}(\mathbf{x}, \varepsilon)=\left\{i \in\{1, \cdots, I\} \mid g_{i}(\mathbf{x}) /\left\|\nabla g_{i}(\mathbf{x})\right\| \geq-\varepsilon\right\}
$$

は正規化された $\varepsilon$-有効制約の添字集合とする。 $\varepsilon$-有効制約とはそ の点から距離 $\varepsilon$ 以内で有効となる制約条件の集合である，異なる二 つの $\varepsilon$ をえた場合の $\varepsilon$-線形化錐の例を図4に示す. 図4において も灰色の線で塗られた領域が集合 $\Omega$ を, 灰色に塗られた領域が与 えられた $\varepsilon$ に対応する $\varepsilon$-線形化錐をそれぞれ表している。 $\varepsilon$-線形 化錐とは距離 $\varepsilon$ 内で集合 $\Omega$ を局所的に線形近似するものである.

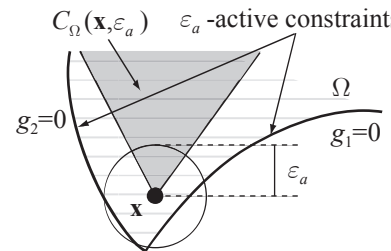

(a) $\varepsilon=\varepsilon_{a}$ の場合

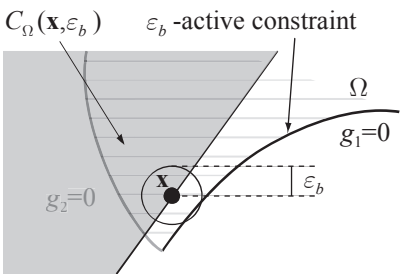

(b) $\varepsilon=\varepsilon_{b}$ の場合
図 $4 \varepsilon$-線形化錐の例

このとき, Algorithm 1により生成される $\left\{\mathbf{x}^{k}\right\},\left\{\Delta_{k}\right\}$ を $\varepsilon$-線形化錐 に与えると, 関係

$$
T_{\Omega}(\hat{\mathbf{x}}) \subset \lim _{k \in \mathcal{K}} C_{\Omega}\left(\mathbf{x}^{k}, \Delta_{k}\right)
$$

が成り立つような部分列 $\left\{\mathbf{x}^{k}\right\}_{k \in \mathcal{K}},\left\{\Delta_{k}\right\}_{k \in \mathcal{K}}$ が存在する（refining subsequenceとよばれ，詳しくはAppendix Dを参照されたい）。よっ て，条件1における集合 $S$ を $\varepsilon$-線形化錐 $C_{\Omega}\left(\mathbf{x}^{k}, \Delta_{k}\right)$ と与えてもよい. 錐の生成元を求める方法は計算幾何学の分野で良く研究されており, そのような方法 ${ }^{14)} に よ り \varepsilon-$-線形化錐を

$$
C_{\Omega}\left(\mathbf{x}^{k}, \Delta_{k}\right)=\left\{\mathbf{d} \in \mathbb{R}^{n} \mid \mathbf{d}=\sum_{i=1}^{n_{T}} u_{i} \mathbf{t}_{i} \text { for } u_{i} \geq 0\right\}
$$

と特定できる．ここで， $\mathbf{t}_{i} \quad\left(i=1, \cdots, n_{T}\right)$ は錐 $C_{\Omega}\left(\mathbf{x}^{k}, \Delta_{k}\right)$ の生成元 $n_{T}$ は生成元の数と寸る. 区間 $[0,1]$ 上での一様分布 $U[0,1]$ に従いラ ンダム発生させた係数 $r_{i} \sim U[0,1] \quad\left(i=1, \cdots, n_{T}\right)$ を $\mathbf{t}_{i}$ に乗じて和をと ることにより，錐 $C_{\Omega}\left(\mathbf{x}^{k}, \Delta_{k}\right)$ 内のランダム方向ベクトル

$$
\sum_{i=1}^{n_{T}} r_{i} \mathbf{t}_{i} \in C_{\Omega}\left(\mathbf{x}^{k}, \Delta_{k}\right)
$$

をいくつか生成させ，これらを探索方向集合 $D_{k}$ とする．このよう な方法でも条件1を満たすことができる (Appendix D参照)。錐 $C_{\Omega}\left(\mathbf{x}_{k}, \Delta_{k}\right)$ の生成元とランダム探索方向集合の例を図5に示す. 図 5でも灰色の線で塗られた領域が集合 $\Omega$ を，灰色に塗られた領域が 錐 $C_{\Omega}\left(\mathbf{x}_{k}, \Delta_{k}\right)$ をそれぞれ表している.また， $\mathbf{t}_{1}, \mathbf{t}_{2}, \mathbf{t}_{3}$ は錐の生成元 を表しており，この場合 $n_{T}=3$ である。 これら $\mathbf{t}_{1}, \mathbf{t}_{2}, \mathbf{t}_{3}$ の非負線形 結合により錐内の点を表現できる。図 3 と図5を比較することによ り，制約関数の感度情報を用いて実行可能領域を局所的に近似すれ ば有効な探索方向を効率的に生成できることがわかる。(7)に示さ れるような方法に基づく探索方向の生成は新規な提案である. 


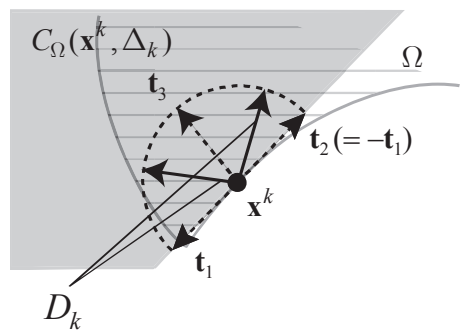

図 5 錐内での方向ベクトルのランダム生成

\section{4. 二次近似モデルの併用}

前節までの方法により局所最適解への大域的収束性が確率的に保 証される，ただし，実用上では有限回の試行における収束性の速さ が重要となる。平滑とみなせるような関数のみからなる問題であれ ば，勾配情報に基づく非線形計画法に比べて直接探索法は収束性の 速さで劣る ${ }^{15)}$. そのような久点を補うために, 寸でに探索された点 の情報から関数の勾配および曲率を近似して探索を行う方法の併用 を考える。このような近似関数を用いるアプローチは surrogate approachあるいはmetamodeling として構造最適化の分野で研究され いる例えば16). ただし，このようなアプローチの多くは発見的方法に 分類されるものであり, 理論的根拠を欠くことが多い. 本提案法が 属する直接探索法系の方法はこのような発見的方法との併用が可能 であり，さらに収束性の議論には何ら影響しないという利点を持つ. 逆に言えば，直接探索法は発見的方法に対して大域的収束性を保証 するための理論的枠組の一つである。ここでは直接探索法との組み 合わせが効率的と報告 ${ }^{17)}$ されているMinimum Frobenius Norm models $^{8)}$ (以下, MFNモデル) による探索をAlgorithm 1のSearch step で行う.MFNモデルとは二次近似モデルであり, 二次多項式の項 数に比べてデータ点が少ないような劣決定系 ( underdetermined system）においてヘッセ行列の行列ノルムが最も小さくなるように 選ばれる二次多項式モデルである。文献17)に詳細が示されている ので，ここでは概要を述べるにとどめる.

Algorithm 1において第 $k$ 回目の繰り返しが終わるまでに探索され た探索点の数を $N(k)$, このような探索点からなる集合を $Y_{k}=\left\{\mathbf{y}^{1}, \mathbf{y}^{1}, \cdots, \mathbf{y}^{N(k)}\right\} \subset \mathbb{R}^{n}$ と表す. Poll stepにより $\mathbf{x}^{k}$ まわりの点の 情報が蓄積されているので，近似モデルの対象領域を

$$
R_{k}=\left\{\mathbf{x} \in \mathbb{R}^{n} \mid\left\|\mathbf{x}-\mathbf{x}_{k}\right\| \leq \Delta_{k}\right\}
$$

ととる. 第 $k$ 回目の繰り返しのSearch step開始時点では, 第 $k-1$ 回 目の繰り返し終了時から新たな探索を行っていないので $Y_{k-1} \cap R_{k-1}$ からデータ点を選ぶ。ここでは逐次的Maxi-Min距離計画 ${ }^{18)}{ }^{19)}$ を用 いて部分集合 $S_{k} \subset\left(Y_{k-1} \cap R_{k-1}\right)$ を選ぶ. ここで, よい近似関数を得 るためには $Y_{k-1} \cap R_{k-1}$ に十分な数の探索点が含まれている必要があ る. Algorithm 1において毎回Poll stepを行う理由は領域 $R_{k-1}$ 内で十 分な数の探索点をSearch step に提供するためである. 関数 $f_{i}$ $\left(i=1, \cdots, I_{1}\right)$ および $g_{i} \quad\left(i=I+1, \cdots, I_{2}\right)$ についてデータセット $S_{k}$ を 用いて作られるMFNモデルをそれぞれ $\tilde{f}_{i}\left(\mathbf{x} ; S_{k}\right)$ および $\tilde{g}_{i}\left(\mathbf{x} ; S_{k}\right)$ と表 す.このとき, 補助変数 $s_{f}$ および $s_{g} \geq 0$ を用いて問題

$$
\begin{array}{cl}
\underset{\mathbf{x}}{\operatorname{minimize}} & s_{f}+\mu s_{g} \\
\text { subject to } & \mathbf{A x} \leq \mathbf{b}, \\
& g_{i}(\mathbf{x}) \leq 0 \quad(i=1, \cdots, I), \\
& \tilde{f}_{i}\left(\mathbf{x} ; S_{k}\right) \leq s_{f} \quad\left(i=1, \cdots, I_{1}\right), \\
& \tilde{g}_{i}\left(\mathbf{x} ; S_{k}\right) \leq s_{g},\left(i=I+1, \cdots, I_{2}\right), \\
& \left\|\mathbf{x}-\mathbf{x}_{k-1}\right\| \leq \Delta_{k-1}, s_{g} \geq 0
\end{array}
$$

を定義する. 問題(9)に含まれる関数はす心゙て平滑な連続微分可能 関数であり，感度解析も容易に行える，感度情報を用いた非線形計 画法により問題(9)を解き，これをSearch stepにおける探索とする. なお，仮定1が成り立てば，元問題(1)を解くことに比べ問題(9)を解 くために要する計算時間は十分小さい.

\section{3. 数值解析例}

\section{1. 問題設定}

制振構造の設計において定量的な性状把握のために時刻歴応答解 析は欠かせないものである. 鋼材ダンパーは他のダンパーに比べて 適用件数が多く，その中でもエネルギー吸収量の多さや施工性の良 さから座屈拘束ブレースが制振構造において広く用いられている. ここでは，時刻歴応答を考慮した設計問題の解析例として座屈拘束 ブレースを有する鋼構造建物の設計問題を扱う.

図6に示す10層3スパンのブレース付き鋼構造平面骨組モデルを考 える，全部材数は90であり，梁部材にはH形鋼，柱部材には角形鋼 管，ブレース部材には座屈拘束ブレースの使用を想定する．柱梁部 材および座屈拘束ブレースの中心鋼材にはSN490級鋼を用いる。断 面符号 G1 から G20 梁部材断面, 断面符号C1から C8 柱部材断面, 断面符号B1からB10を座屈拘束ブレース部材断面として, 対称性を 考慮して図6に示寸ように与える.

$n=38$ と与え, 設計変数 $\mathbf{x}=\left(x_{1}, \cdots, x_{38}\right)^{T}$ と図6の断面符号を表 1 のように関係づける. 以降，対応する部材断面を第 $i$ 部材断面と参 照する. すべての部材種について第 $i$ 部材断面の断面積 $A_{i}$ に設計 変数 $x_{i}$ を対応させて

$$
A_{i}=x_{i} \quad(i=1,2, \cdots, 38)
$$

と与える．なお，座屈拘束ブレース部材において中心鋼材の断面積 を表すとする．さらに梁部材，柱部材については第 $i$ 部材断面の断 面二次モーメント $I_{i}$, 断面係数 $Z_{i}$, 塑性断面係数 $Z_{p i}$ との関係を

$$
\left.\begin{array}{l}
\text { [柱] } I_{i}=1.2 x_{i}^{2}, Z_{i}=0.8 x_{i}^{1.5}, Z_{p i}=0.9 x_{i}^{1.5} \quad(i=1,2, \cdots, 8), \\
\text { [梁] } I_{i}=4.0 x_{i}^{2}, Z_{i}=1.5 x_{i}^{1.5}, Z_{p i}=1.6 x_{i}^{1.5} \quad(i=9,10, \cdots, 28)
\end{array}\right\}
$$

と与える. 以降では表記の煩雑さを避けるために，第 $i$ “部材断面” の断面積および第 $i$ “部材”の断面積に同じ記号 $A_{i}$ を用い, $I_{i}, Z_{i}$, $Z_{p i}$ についても同様に表記する。次に設計変数の上下限值を

$$
\left.\begin{array}{lll}
\text { [柱] } & 200 \mathrm{~cm}^{2} \leq x_{i} \leq 1500 \mathrm{~cm}^{2} & (i=1,2, \cdots 8), \\
\text { [梁] } & 70 \mathrm{~cm}^{2} \leq x_{i} \leq 250 \mathrm{~cm}^{2} & (i=9,10, \cdots, 28), \\
\text { [ブレース] } & 20 \mathrm{~cm}^{2} \leq x_{i} \leq 100 \mathrm{~cm}^{2} & (i=29,30, \cdots, 38)
\end{array}\right\}
$$

と与える. $\mathrm{SN} 490$ 級鋼の場合, 鋼材強度 $\sigma_{y}=325 \mathrm{~N} / \mathrm{mm}^{2}$ であるの で座屈拘束ブレースの降伏軸力を $650 \mathrm{kN}$ から $3,250 \mathrm{kN}$ と与えこと に相当する. 


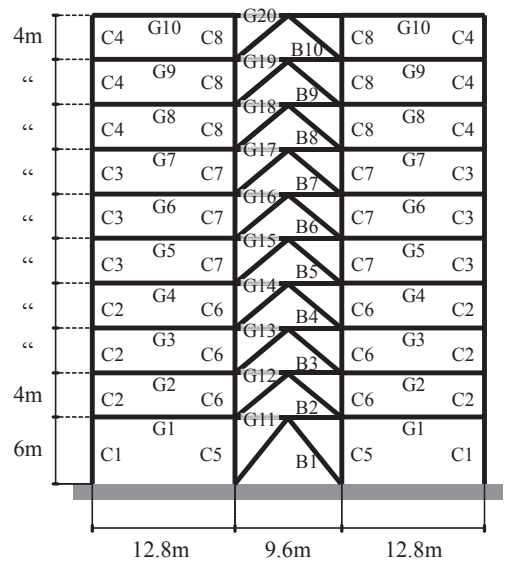

図 6 ブレース付き 10 層 3 スパン鋼構造平面骨組モデル

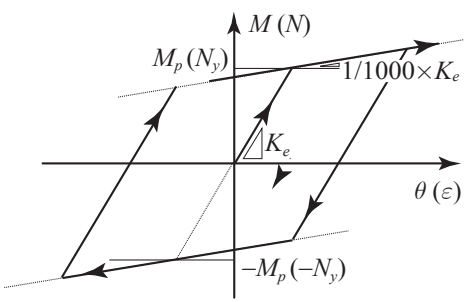

図 7 復元力特性

表 1 断面符号と設計変数

\begin{tabular}{cc|cccc|cc}
\hline $\begin{array}{c}\text { 断面 } \\
\text { 符号 }\end{array}$ & $\begin{array}{c}\text { 設計 } \\
\text { 変数 }\end{array}$ & $\begin{array}{c}\text { 断面 } \\
\text { 符号 }\end{array}$ & $\begin{array}{c}\text { 設計 } \\
\text { 変数 }\end{array}$ & $\begin{array}{c}\text { 断面 } \\
\text { 符号 }\end{array}$ & $\begin{array}{c}\text { 設計 } \\
\text { 変数 }\end{array}$ & $\begin{array}{c}\text { 断面 } \\
\text { 符号 }\end{array}$ & $\begin{array}{c}\text { 設計 } \\
\text { 変数 }\end{array}$ \\
\hline \hline $\mathrm{C} 1$ & $x_{1}$ & $\mathrm{G} 1$ & $x_{9}$ & $\mathrm{G} 11$ & $x_{19}$ & $\mathrm{~B} 1$ & $x_{29}$ \\
$\mathrm{C} 2$ & $x_{2}$ & $\mathrm{G} 2$ & $x_{10}$ & $\mathrm{G} 12$ & $x_{20}$ & $\mathrm{~B} 2$ & $x_{30}$ \\
$\mathrm{C} 3$ & $x_{3}$ & $\mathrm{G} 3$ & $x_{11}$ & $\mathrm{G} 13$ & $x_{21}$ & $\mathrm{~B} 3$ & $x_{31}$ \\
$\mathrm{C} 4$ & $x_{4}$ & $\mathrm{G} 4$ & $x_{12}$ & $\mathrm{G} 14$ & $x_{22}$ & $\mathrm{~B} 4$ & $x_{32}$ \\
$\mathrm{C} 5$ & $x_{5}$ & $\mathrm{G} 5$ & $x_{13}$ & $\mathrm{G} 15$ & $x_{23}$ & $\mathrm{~B} 5$ & $x_{33}$ \\
$\mathrm{C} 6$ & $x_{6}$ & $\mathrm{G} 6$ & $x_{14}$ & $\mathrm{G} 16$ & $x_{24}$ & $\mathrm{~B} 6$ & $x_{34}$ \\
$\mathrm{C} 7$ & $x_{7}$ & $\mathrm{G} 7$ & $x_{15}$ & $\mathrm{G} 17$ & $x_{25}$ & $\mathrm{~B} 7$ & $x_{35}$ \\
$\mathrm{C} 8$ & $x_{8}$ & $\mathrm{G} 8$ & $x_{16}$ & $\mathrm{G} 18$ & $x_{26}$ & $\mathrm{~B} 8$ & $x_{36}$ \\
& & $\mathrm{G} 9$ & $x_{17}$ & $\mathrm{G} 19$ & $x_{27}$ & $\mathrm{~B} 9$ & $x_{37}$ \\
& & $\mathrm{G} 10$ & $x_{18}$ & $\mathrm{G} 20$ & $x_{28}$ & $\mathrm{~B} 10$ & $x_{38}$ \\
& & & & & & &
\end{tabular}

表 2 荷重条件

\begin{tabular}{l|l}
\hline 床重量 & 基淮階 $: 8.3 \mathrm{kN} / \mathrm{m}^{2}, \mathrm{R}$ 階 $: 10.5 \mathrm{kN} / \mathrm{m}^{2}$ \\
\hline 建物重量 & 基準階 $: 1865.5 \mathrm{kN}, \mathrm{R}$ 階 : $2362.3 \mathrm{kN}$ \\
\hline 長期荷重 (一様分布荷重 $)$ & 基淮階 $: 53.0 \mathrm{kN} / \mathrm{m}, \mathrm{R}$ 階 $: 67.1 \mathrm{kN} / \mathrm{m}$ \\
\hline 地震力 & Ai 分布 $\left(\mathrm{C}_{0}=0.2\right)$ に基づく外力分布 \\
\hline
\end{tabular}

問題(1)の表記にあわせた目的関数として, ブレース付き鋼構造 建物のコスト関数

$$
f_{0}(\mathbf{x})=f_{1}(\mathbf{x})=\sum_{i \in \mathcal{M}_{C} \cup \mathcal{M}_{G}}\left(c_{1} \rho l_{i} A_{i}\right)+\sum_{i \in \mathcal{M}_{B}}\left(c_{2} \sigma_{y} A_{i}-c_{3} l_{i}+c_{4}\right)
$$

を与える.ここで， $\mathcal{M}_{C}, \mathcal{M}_{G}, \mathcal{M}_{B}$ はそれぞれ柱部材，梁部材， ブレース部材の部材番号からなる集合, $\rho=7.8 \mathrm{~g} / \mathrm{cm}^{3}$ は鋼材密度, $\sigma_{y}$ は鋼材強度すなわち $\sigma_{y} A_{i}$ は第 $i$ 部材の降伏軸力, $l_{i}$ は第 $i$ 部材 の部材長を表す. コスト係数として $c_{1}=25 \times 10^{-6} / \mathrm{g}, c_{2}=0.01 / \mathrm{kN}$, $c_{3}=0.1 / \mathrm{cm}, c_{4}=90$ を与える.

許容応力度設計に基づく制約条件を簡略化して課す. 直交スパン を $6.4 \mathrm{~m}$ ，フロアごとの支配面積を $35.2 \mathrm{~m} \times 6.4 \mathrm{~m}=225.28 \mathrm{~m}^{2}$ として， 荷重条件を表2のように与える。また，剛床仮定が成り立つとする.
これらの条件の下で弾性設計に基づく制約条件として

層間変形角制約： $\quad \frac{\delta_{k}^{S}}{h_{k}} \leq \frac{1}{200} \quad(k=1, \cdots, 10)$

部材端許容応力度比制約：

[柱]

[梁]

$$
\left.\begin{array}{l} 
\pm \frac{M_{i}^{j}}{Z_{i} f_{b i}}-\frac{N_{i}}{A_{i} f_{c i}} \leq 1 \quad\left(i \in \mathcal{M}_{C}, j=1,2\right), \\
\pm \frac{M_{i}^{j}}{Z_{i} f_{b i}} \leq 1 \quad\left(i \in \mathcal{M}_{G}, j=1,2\right),
\end{array}\right\}
$$$$
\text { [ブレース }] \pm \frac{N_{i}}{A_{i} f_{t i}} \leq 1 \quad\left(i \in \mathcal{M}_{B}\right)
$$

を与える．ここで， $A_{i}, Z_{i}$ はそれぞれ第 $i$ 部材の断面積および断面 係数， $M_{i}^{j}, N_{i}$ はそれぞれ長期あるいは短期荷重時の第 $i$ 部材の第 $j$ 端曲げモーメントおよび第 $i$ 部材軸力（引張力）， $f_{c i}, f_{t i}, f_{b i}$ は それぞれ $i$ 部材の長期あるいは短期荷重時の許容圧縮応力度, 許容

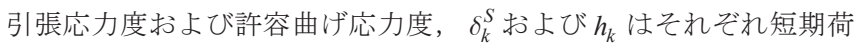
重時の第 $k$ 層の層間変形角および第 $k$ 層の階高と寸る，なお，剛床 仮定の下では梁部材に軸変形は生じないので, 梁部材の断面積は剛 性に直接関係せず，コスト関数(13)にのみ影響を与える。しかし， 関係式(10),(11)より，断面二次モーメント，断面係数, 塑性断面係 数は断面積の関数なので, 骨組の応答は断面積の関数となる.

次に弾塑性時刻歷応答の最大值について制約条件を課すことを考 える. 第 $i$ 入力地震動の地動加速度を $\mathbf{g}_{0}^{(i)}$ と表す. 最大速度振幅が $50 \mathrm{~cm} / \mathrm{s}$ となるように規準化された観測記録波 ${ }^{20)}$ としてE1 Centro 1940

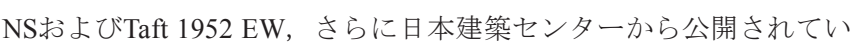
る模擬地震動である $\mathrm{BCJ}-\mathrm{L} 2{ }^{7}$ の計三波を設計用入力地震動として用 いる. 第 $i$ 地震動に対する設計 $\mathbf{x}$ の第 $j$ 層の時刻 $t$ における層間变 形を $\delta_{j}\left(\mathbf{x}, t ; \mathbf{g}_{0}^{(i)}\right)$ と表す. このとき，条件

$$
\max _{t \geq 0}\left|\delta_{j}\left(\mathbf{x}, t ; \mathbf{g}_{0}^{(i)}\right)\right| / h_{j} \leq \frac{1}{100} \quad(i=1,2,3, \quad j=1,2, \cdots, 10)
$$

を与える，応答評価にはNewmark $\beta$ 法による骨組モデルの時刻歷応 答解析を行う。ここで，平均加速度法として $\beta=1 / 4$, 時間刻み $\Delta t=0.01 \mathrm{sec}$ を与える. 各部材を梁要素としてモデル化し要素端部 に設けた塑性ヒンジによって部材の塑性化を表寸材端ばねモデルを 用いる。材端ばねの復元力特性として, 逆対称変形時の梁要素の曲 げモーメント $M$ と材端回転角 $\theta$ の関係が図7に示すようなBi-linear 型となるように与える ${ }^{2)}$. 図7で $M_{p}$ は部材の全塑性モーメントを表 す．材端ばねモデルを用いた骨組の動的弾塑性解析の詳細について は例えば文献21)を参照されたい.さらに, ブレース部材の軸力 $N$ と軸ひずみ $\varepsilon$ の関係も図7に示すようなBi-linear型として与える. 図7で $N_{y}$ はブレースの降伏軸力を表す. モデルの減衰係数として, 1 次の減衰定数を $2 \%$ にえた初期剛性比例減衰を与える.

その他の制約条件として，上層の柱が下層の柱よりも太くならな いような制約条件

$$
x_{i} \geq x_{i+1} \quad(i=1,2,3,5,6,7)
$$

および，柱梁接合部の曲げ耐力比が 1.5 以上となるような制約条件

$$
\left(\sum_{i \in \mathcal{J}_{k}^{C}} M_{p i}\right) /\left(\sum_{i \in \mathcal{J}_{k}^{G}} M_{p i}\right) \geq 1.5 \quad(k \in \mathcal{J})
$$

を与える.ここで, $\mathcal{J}$ は最上層の柱頭部および最下層の柱脚部を 除いた柱梁接合部の節点番号に対応する集合とし， $\mathcal{J}_{k}^{G}$ おび $\mathcal{J}_{k}^{C}$ はそれぞれ第 $k$ 節点にとりつく梁部材番号および柱部材番号に対応 
する集合, $M_{p i}=\sigma_{y} Z_{p i}$ は第 $i$ 部材の全塑性モーメントとする.

第1節で述べたように制約条件(16)は非平滑関数である. 問題(1) の表記に対応させて以上を整理すると, 表3に示すようになる.

表 3 問題（数值解析例）の整理

\begin{tabular}{l|l}
\hline 目的関数 : $f_{0}(\mathbf{x})=f_{1}(\mathbf{x})$ & コスト関数 $(13)$ \\
\hline 制約関数 $:$ & 層間変形角制約 $(14)$ \\
$g_{i}(\mathbf{x}) \quad(i=1, \cdots, I)$ & 部材端許容応力度比制約 $(15)$ \\
& 柱梁接合部曲げ耐力比制約 $(18)$ \\
\hline 制約関数 : & 時刻歷応答最大層間変形角制約 $(16)$ \\
$g_{i}(\mathbf{x}) \quad\left(i=I+1, \cdots, I_{2}\right)$ & 上下限制約 $(12)$ \\
\hline 線形制約 $: \mathbf{A x} \leq \mathbf{b}$ & 柱断面大小関係制約 $(17)$ \\
&
\end{tabular}

\section{2. 比較に用いる最適化法}

次の4種類の最適化法を適用し比較・検討を行う.

(a) SQP：差分計算による感度近似を用いた逐次二次計画法 ${ }^{22)}$

(b) MADS : 感度情報を用いない直接探索法の一種であるMesh Adaptive Direct Search法 ${ }^{23)}$

(c) DST：本提案法（MFNモデルを用いた探索を併用しない。）

(d) DSTMFN : 本提案法（MFNモデルを用いた探索を併用する。） (a)のSQPは感度情報を利用する非線形計画法の標準的なものである. (b)のMADSは非平滑最適化問題に適用可能な直接探索法の一つに 分類される. MADSは感度情報を全く利用せず，この点が本提案法 (c)との大きな相違点である. (c), (d)は本提案法である. これらの違 いはSearch stepにおいてMFNモデルを用いた探索を行うか否かであ り，(c)では毎回Search stepをスキップする．微分不可能な点を含む 本問題に対して, SQPでは局所解への収束性が保証されず，一方，

MADS, DST, DSTMFNでは確率1で保証される. 条件設定の詳細 を以下に示す. なお, SQP, MADSで以下に示されていないものは 文献22) 23)の標準值を用いている.

[共通]

- 設計変数の上下限值を 0 から 1 に正規化する。DST, DSTMFN, MADSでは設計変数の大きさを揃えることが望 ましい，SQPではその必要性はないが，条件を合わせるた めに全法で設計变数の正規化を行う。

・制約関数を適当にスケーリングした上で, 違反許容值を $10^{-4}$ と与える. 寸なわち, $\max \left\{g_{1}(\mathbf{x}), \cdots, g_{I_{2}}(\mathbf{x})\right\}>10^{-4}$ であ れば非許容解とする.

- 終了条件は時刻歴応答解析の実行回数のみとする. [SQP]

・ 問題(1)として与える. (ソルバー内部でメリット関数化する ので問題(2)への書き換えは不要である)

- 制約関数(14),(15),(18)については感度解析を行い, 制約関 数(16)については前進差分による感度近似を行う.

・正規化された設計変数の上下限值の差に $10^{-4}$ を乗じた值, 寸 なわち $10^{-4}$ を差分計算時に差分幅として与える。

- 差分計算のための応答関数評価も関数実行回数に含める. [MADS]

・ 問題(1)として与える.（ソルバー内部でペナルティ関数化す
るので問題 $(2)$ へ書き換えは不要である)

- 感度解析を行わない,

[DST, DSTMFN]

- 問題(1)を問題(2)の形に書き換え,ペナルティ関数の係数を $\mu=100$ と与える. なお，この值は初期值であり，後で述べ る操作により $\mu$ を適応的に増加させる.

・制約関数(14),(15),(18)については感度解析を行う。

- 時刻歴応答解析を行わずとも設計 $\mathbf{x}$ が非許容解であるとわ かる場合，才なわち $\max \left\{g_{1}(\mathbf{x}), \cdots, g_{I}(\mathbf{x})\right\}>10^{-4}$ のとき，時刻 歴応答解析は行わない.

・直接探索法において標準的に用いられるパラメータ值8)であ る $\beta_{1}=0.5, \beta_{2}=2$ を与え, 設計変数を0から 1 に正規化した ことから $\Delta_{0}=0.2, \Delta_{\max }=0.4$ を与える.

- 第 $k$ 回目のStep size parameter updateで「成功」と宣言されて いた場合に確率 0.1 でステップサイズを $\Delta_{k+1}=0.8$ に増加さ せる.

- 第 $k$ 回目のStep size parameter updateで「失敗」と宣言され, かつ非平滑関数の制約違反值が $10^{-4}$ より大きい場合，すな わち $\max \left\{g_{I+1}\left(\mathbf{x}^{k}\right), \cdots, g_{I_{2}}\left(\mathbf{x}^{k}\right)\right\}>10^{-4}$ となる場合, その時点で のペナルティ関数の係数 $\mu$ を 1.2 倍に増加して更新する.

- 非線形関数 $g_{i}(i=1, \cdots, I)$ の感度係数は感度解析を行った点 の近傍においてのみ有効であるので， $\Delta_{k} \leq 0.1$ の場合にの み用いる。

・DSTMFNでのSearch stepは1ケースにつき最大40回行う.

・DSTMFNの1回のSearch stepでは, 改良点が発見されるまで 初期值を変えた探索を最大 5 回行う。

\section{3. 解析結果}

設計変数の初期值すべてに上限值を与えたものをCase 0 , 実行可 能領域 $\Omega$ 内でランダムに生成した異なる 5 種類の初期值をそれぞれ 与えたものをCase 1〜Case 5とし，計6ケースを扱う. 表3に示され ているように時刻歴応答最大層間変形角制約(16)は $\Omega$ に含まれない, 実際，Case 0の初期值は制約(16)を満たしているが，Case 1〜Case 5 の初期值は制約(16)を満たさない. 時刻歴応答についての条件を満 た寸設計解は自明ではなく, それを求めることは容易ではないので, 現実的な状況に近い設定である。

全手法, 全Caseについて時刻歴応答解析の実行回数 3,800 $(=100 n)$ 回までに探索された最良な許容解に対応する目的関数值を 表4にまとめる。許容解が求まらなかった場合を記号“一”で示寸. SQPおよびMADSに比べて提案法であるDSTおよびDSTMFNは初期 值依存性の小さいロバストな方法であり, DSTMFNが最も優れて いることが表4よりわかる。なお，DSTおよびDSTMFNにおけるパ ラメータについて， $\mu$ は適応的に変化させるのでその影響は少な いが， $\Delta_{0}, \Delta_{\max }, \beta_{1}, \beta_{2}$ に異なる值を与えた場合には異なる結果が 得られることが予想される. 本解析例では，既往の文献に示された 標準的なパラメータ值 ${ }^{8}$ を用いており，その変更の影響は検討して いない，ただし，雑音性を示寸非平滑な問題への直接探索法の有効 性はこれまでに報告されており ${ }^{8)}$ ，パラメータのチューニングをせ ずともある程度の性能を示すと考えられる.

全手法で許容解が得られたCase 0について検討を行う. Case 0では 
すべての設計変数について上限值を初期值として与えている。これ は時刻歴応答最大層間変形角制約(16)を含めすべての制約条件を満 足する初期值であるが，コストを考えると過剩な断面設計であり大 域的な最適解からは遠いものであると予想される。時刻歴応答解析 の実行回数3,800回までに探索された各法での許容解の目的関数值 の履歴を図8 亿示す. 図8 亿おいて, 実行回数が少ない領域のDST・ DSTMFNとMADSを比較することにより感度情報利用の意義, 寸な わち収束の速さの向上が読み取れる。一方，SQPでは，非許容解に 収束してそこから抜け出せなくなる現象が観察され, 初期值よりも 良い許容解を発見することができなかった。この結果は，1節で述 べたように応答に局所的な底が多数存在することに起因する。なお， SQPでは差分幅を $10^{-4}$ に固定して感度近似を行ったが，解析結果 は差分幅に依存する可能性がある。ただし, 適切な差分幅を事前に 決定することは容易ではなく, 直接探索法では, 差分幅に対応する ステップサイズを適応的に変化させることにより, パラメータ依存 性を回避している.

DSTおよびDSTMFNについて，全ケースの目的関数值の履歴を

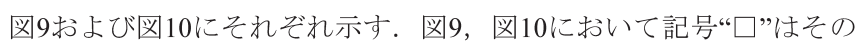
時点で初めて許容解を発見したことを示す. 図 9 と図10を比べるこ とにより，MFNモデルの併用により解法が改善されていることが わかる. また, 時刻歴応答解析の実行回数 3,800 回以内において Search stepでMFNモデルを用いた探索回数すなわち問題(9)を解いた 回数，およびそのうち探索が成功であった回数を表 5 に示す.

全法，全ケースを通じての最良解であるDSTMFNのCase 3で得ら れた設計解について検討を行う。設計解の固有周期は 1 次が $1.50 \mathrm{sec}$, 2次が $0.51 \mathrm{sec}$ であった。設計解の断面積分布を線の太さに比例させ て描いたものを図11に示す。この設計解では，梁部材として22.3ton， 柱部材として46.3tonの鋼材重量となる. 各地震動に対する最大応答 層間変形角を図 12 に, 最大応答層せん断力と座屈拘束ブレース材 （BRB）の降伏軸力とをあわせて図13に示す，全Case中の最良解と なるこの設計解では, 与えられたすべての設計用地震動に対して 柱・梁部材の時刻歴応答は弾性限以下にとどまり, ブレース部材の み塑性化するような応答性状を示した。 なお，解析上では柱・梁部 材の塑性化を考慮しており, 実際, 表4に示された設計解には柱・梁 が塑性化するものも含まれている.

表 4 各法・各 Case における最良の許容解に対応する目的関数值

\begin{tabular}{c|cccc}
\hline Case & SQP & MADS & DST & DSTMFN \\
\hline \hline 0 & 7,802 & 5,485 & 3,853 & 2,775 \\
\hline 1 & - & - & 3,909 & 2,985 \\
2 & - & 3,255 & 3,399 & 2,838 \\
3 & - & 4,084 & 3,755 & 2,638 \\
4 & - & - & 3,697 & 2,976 \\
5 & - & - & 3,596 & 2,941 \\
\hline 平均 & 7,802 & 4,274 & 3,702 & 2,858 \\
最良 & 7,802 & 3,255 & 3,399 & 2,638 \\
標本標準偏差 & - & 1,127 & 185 & 136 \\
\hline
\end{tabular}

表 5 MFN モデルを用いた探索回数（DSTMFN，Case 0～5）

\begin{tabular}{c|c|ccccc|c}
\hline Case & 0 & 1 & 2 & 3 & 4 & 5 & (平均) \\
\hline \hline 探索回数 & 113 & 139 & 131 & 130 & 132 & 155 & 133.3 \\
成功回数 & 31 & 18 & 24 & 22 & 21 & 16 & 22.0 \\
\hline
\end{tabular}

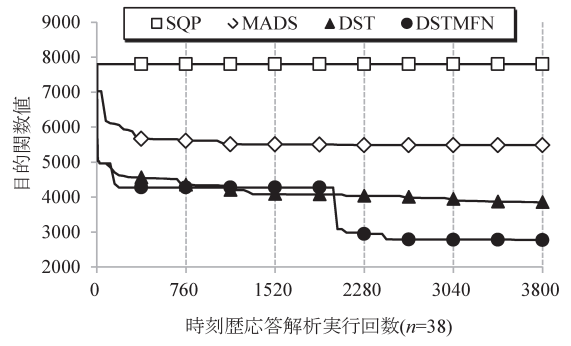

図 8 目的関数值の履歴（全法, Case 0)

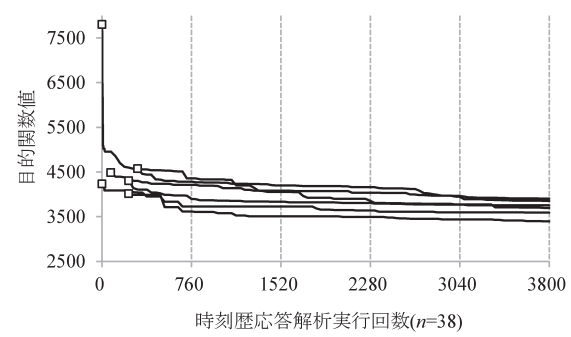

図 9 目的関数值の履歴（DST, Case 0〜 5)

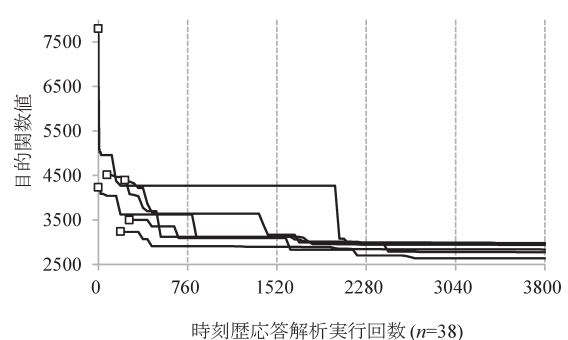

図 10 目的関数值の履歴（DSTMFN， Case 0 5)

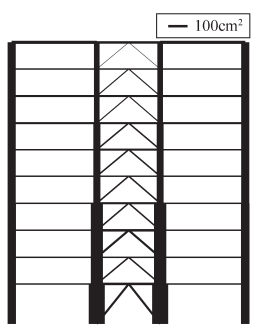

図 11 設計解の断面積分布 (DSTMFN, Case 3)

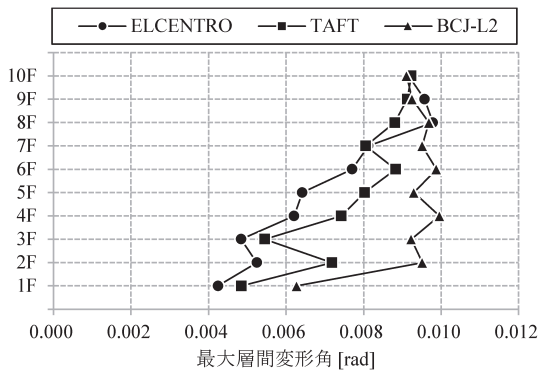

図 12 最大応答層間変形角 (DSTMFN, Case 3)

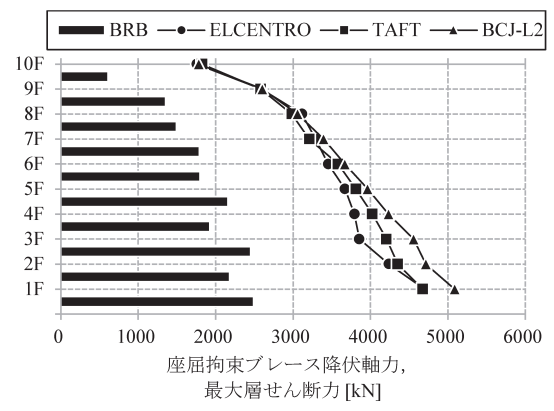

図 13 座屈拘束ブレース降伏軸力, 最大応答層せん断力 (DSTMFN, Case 3) 
実務設計上で考慮す心゙き条件は, 当然ながらここで取り扱ったも の以外に多数存在する. 本研究は基礎的研究段階にあり, 未だ多く の課題が残されている.ただし，ここで扱ったような単純化した例 においてでさえ, 一般的な非線形計画法では良い設計解を得られな い可能性が高い。この種の問題に特化した手法が必要である.

\section{4. まとめ}

弹塑性時刻歴応答解析法を応答評価法として用いることを考慮し, 複数の設計用地震動に対する動的応答の最大值を制約条件として考 慮したコスト最小化問題に適した方法を提案した．得られた結論は 以下の通りである.

（1）時刻歴応答解析を含む耐震設計の問題を考えた場合に，連続微 分不可能な関数と可能な関数とが混在した問題となることが一 般的であることを指摘し, そのような問題に対して大域的収束 性を確率的に保証できる方法を提案した。

(2) 10層3スパンの座屈ブレース付き鋼構造平面骨組モデルの数值 解析例を用いて, 一部の感度情報のみを利用した提案法は他法 と比べて安定して良い許容解を発見することができ,さらに初 期值依存性も小さいことを確認した.

（3）時刻歴応答解析を含む耐震設計の問題への適用においても，応 答関数の勾配および曲率を近似して扱う方法との併用が直接探 索法には有効であることを数值解析例により確認した.

\section{謝辞}

本研究の遂行にあたり, ユニオンシステム株式会社の中川佳久氏 から有益な助言をいただいた。また，本研究は一般社団法人日本鉄 鋼連盟「2011年度鋼構造研究・教育助成事業」の助成を受けて行わ れた。ここに記して感謝の意を表す。

\section{参考文献}

1）金紋廷, 荒木慶一, 山川誠, 田川浩, 五十子幸樹：極大地震動に対する超 高層純ラーメン鋼構造建物の動的応答に及ぼす P- $\Delta$ 効果の影響, 日本建 築学会構造系論文集, Vol.74, No.644, pp.1861-1868, 2009.10

2）評定・評価を踏まえた高層建築物の構造設計実務，（財）日本建築セン ター, 2002

3) F. van Keulen, R.T. Haftka and N.H. Kim: Review of options for structural design sensitivity analysis. Part 1: Linear systems, Comput.Methods Appl.Mech.Eng., Vol.194, No.30, pp.3213-3243, 2005

4) B.S. Kang, G.J. Park and J.S. Arora: A review of optimization of structures subjected to transient loads, Structural and Multidisciplinary Optimization, Vol.31, No.2, pp.81-95, 2006

5) 大崎純 : 不連続特性を有する構造システムの設計感度解析と最適設計, 日本建築学会構造系論文集, No. 465, pp. 147-153, 1994.11

6) J.E. Dennis and R.B. Schnabel: Numerical methods for unconstrained optimization and nonlinear equations, Society for Industrial Mathematics, Philadelphia, 1996

7）建設建築研究所・（財）日本建築センター：設計用入力地震動作成手法技 術指針（案），1992

8) A.R. Conn, K. Scheinberg and L.N. Vicente: Introduction to derivative-free optimization, Society for Industrial Mathematics, Philadelphia, 2009

9) T.G. Kolda, R.M. Lewis and V. Torczon: Optimization by direct search: New perspectives on some classical and modern methods, SIAM Rev, Vol.45, No.3, pp.385-482, 2003

10）山川誠：時刻歴応答解析における微分不可能性を考慮した大域的直接探 索法，構造工学論文集，Vol.58B, pp.319-326, 2012.3

11) C. Audet and J.E. Dennis: Mesh Adaptive Direct Search Algorithms for Constrained Optimization, SIAM Journal on Optimization, Vol.17, No.1, pp.188-217, 2006

12) L. Vicente and A. Custódio: Analysis of direct searches for discontinuous functions, Math.Program., pp.1-27, 2011

13) R. Fletcher: Practical Methods of Optimization, Second Edition, Wiley-Interscience, Chichester, 1987

14) K. Fukuda and A. Prodon: Double description method revisited, Combinatorics and Computer Science, M. Deza, R. Euler, and I. Manoussakis, eds., Lecture Notes in Comput. Sci. 1120, pp.91-111, 1996

15) C. Audet, J.E. Dennis and S. Le Digabel: Globalization strategies for mesh adaptive direct search, Computational Optimization and Applications, Vol.46, No.2, pp.193-215, 2010

16) A.I.J. Forrester and A.J. Keane: Recent advances in surrogate-based optimization, Prog.Aerospace Sci., Vol.45, pp.50-79, 2009

17) A.L. Custódio, H. Rocha and L.N. Vicente: Incorporating minimum Frobenius norm models in direct search, Computational Optimization and Applications, Vol.46, No.2, pp.265-278, 2010

18) S.S. Ravi, D.J. Rosenkrantz and G.K. Tayi: Heuristic and special case algorithms for dispersion problems, Oper.Res., Vol.42(2), pp.299-310, 1994

19) G. Rennen: Subset selection from large datasets for Kriging modeling, Structural and Multidisciplinary Optimization, Vol.38, No.6, pp.545-569, 2009

20）高層建築物構造評定委員会：高層建築物の動的解析用地震動について, 日本建築センター, ビルディングレター, 1986.6.

21）藤谷義信, 藤井大地, 野中哲也：パソコンで解く骨組の静的・動的・弾 塑性，丸善株式会社, 2000

22) Optimization Toolbox 6.1 User's Guide, The MathWorks, Inc., Natick, MA, 2011

23) Global Optimization Toolbox 3.2 User's Guide, The MathWorks, Inc., Natick, MA, 2011

24) G. Giorgi, A. Guerraggio, J. Thierfelder and J. Thierfelder: Mathematics of optimization: smooth and nonsmooth case, Elsevier Science, Amsterdam, 2004

25) J. Jahn: Introduction to the theory of nonlinear optimization, 3rd Edition, Springer Verlag, Berlin, 2007

26) F.H. Clarke: Optimization and nonsmooth analysis, Society for Industrial and Applied Mathematics, Philadelphia, 1990

27) M. Capiński and P.E. Kopp: Measure, integral and probability, Second Edition, Springer Verlag, London, 2004

\section{Appendix A : Lipschitz 連続}

Lipschitz連続は次のように定義される例えぱ24)。

\section{定義 A1 (Lipschitz連続)}

関数 $f: X \rightarrow \mathbb{R}$ について, 条件

$$
\left|f(\mathbf{x})-f\left(\mathbf{x}^{\prime}\right)\right| \leq L\left\|\mathbf{x}-\mathbf{x}^{\prime}\right\| \text { for } \forall \mathbf{x}, \mathbf{x}^{\prime} \in X .
$$

を満たすような定数 $L \geq 0$ が存在するとき， $f$ は $X$ 上でLipschitz 条件を満たす，あるいはLipschitz連続であるという。また，

$$
\left|f(\mathbf{x})-f\left(\mathbf{x}^{\prime}\right)\right| \leq L\left\|\mathbf{x}-\mathbf{x}^{\prime}\right\| \quad \text { for } \forall \mathbf{x}, \mathbf{x}^{\prime} \in N(\hat{\mathbf{x}}) \cap X .
$$

を満たすような $\hat{\mathbf{x}}$ の近傍 $N(\hat{\mathbf{x}})$ および定数 $L \geq 0$ が存在するとき，

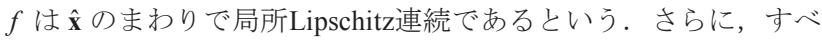
ての $\hat{\mathbf{x}} \in X$ について $\hat{\mathbf{x}}$ のまわりで局所Lipschitz連続であるとき， $f$ は $X$ 上で局所Lipschitz連続であるという.

例えば, $f(x)=|x|$ は $x=0$ において連続微分不可能であるが, $x \in \mathbb{R}$ において Lipschitz 定数 $L=1$ を持つ Lipschitz 連続関数である. 
Appendix B：十分な降下条件（sufficient decrease condition）

文献8)9)に示される内容の概要を示す。 $\Omega \subseteq \mathbb{R}^{n}$ で下に有界な関 数 $f: \mathbb{R}^{n} \rightarrow \mathbb{R}$, 現在の探索点 $\mathbf{x} \in \Omega$, および $\mathbf{x}$ から方向 $\mathbf{d} \in \mathbb{R}^{n}$ に定 数 $\alpha>0$ を乗じた探索点 $\mathbf{x}+\alpha \mathbf{d}$ についての「十分な降下条件 (sufficient decrease condition)」は

$$
f(\mathbf{x}+\alpha \mathbf{d})<f(\mathbf{x})-\rho(\alpha)
$$

と表される.ここで，適当な定数 $0<\kappa_{\text {min }} \leq \kappa_{\text {max }}$ に対し $\kappa_{\text {min }} \leq\|\mathbf{d}\| \leq$ $\kappa_{\max }$ とする. 関数 $\rho:[0,+\infty) \rightarrow[0,+\infty)$ はforcing function と呼ばれ， 次の二つの条件を満たさなければならない

$$
\begin{array}{ll}
\text { (i) } & \lim _{t \downarrow 0} \rho(t) / t=0 \\
\text { (ii) } & \rho\left(t_{1}\right) \leq \rho\left(t_{1}\right) \text { for } t_{1}<t_{2}
\end{array}
$$

\section{Appendix C : 非平滑問題における最適性条件}

点 $\mathbf{x} \in \Omega \subset \mathbb{R}^{n}$ のまわりで局所Lipschitz連続な関数 $f: \mathbb{R}^{n} \rightarrow \mathbb{R}$ につ いて点 $\mathbf{x}$ および方向 $\mathbf{d} \in \mathbb{R}^{n}$ のClarke-Jahn一般化方向微分係数は

$$
f^{\circ}(\mathbf{x} ; \mathbf{d}):=\limsup _{\substack{\mathbf{y} \rightarrow \mathbf{x}, \mathbf{y} \in \Omega \\ t \downarrow 0, \mathbf{y}+t \mathbf{d} \in \Omega}} \frac{f(\mathbf{y}+t \mathbf{d})-f(\mathbf{y})}{t}
$$

と定義される ${ }^{1125)}$.

錐とは $\mathbf{x} \in C, \alpha \in[0, \infty) \Rightarrow \alpha \mathbf{x} \in C$ を満たす集合 $C$ のことである. 点 $\mathbf{x}$ における集合 $\Omega$ の接錐（Bouligand tangent cone）あるいは contingent coneは

$$
T_{\Omega}(\mathbf{x}):=\left\{\mathbf{v} \in \mathbb{R}^{n} \mid \exists t_{k} \downarrow 0, \exists \mathbf{w}_{k} \rightarrow \mathbf{v}, \forall k: \mathbf{x}+t_{k} \mathbf{w}_{k} \in \Omega\right\}
$$

と定義される。一方, 点 $\mathbf{x}$ における集合 $\Omega$ のlarke tangent coneは

$T_{\Omega}^{C l}(\mathbf{x}):=\left\{\mathbf{v} \in \mathbb{R}^{n} \mid \forall \mathbf{y}_{k} \rightarrow_{\Omega} \mathbf{x}, \forall t_{k} \downarrow 0, \exists \mathbf{w}_{k} \rightarrow \mathbf{v}, \forall k: \mathbf{y}_{k}+t_{k} \mathbf{w}_{k} \in \Omega\right\}(\mathrm{C} 2)$

と定義される. 既往の研究 ${ }^{11)}$ では $T_{\Omega}(\mathbf{x})$ と $T_{\Omega}^{C l}(\mathbf{x})$ を区別しているが, 本論ではこれらが一致する場合 (Clarke正則 ${ }^{26)}$ ) を扱うので接錐と して $T_{\Omega}(\mathbf{x})$ のみを扱う.

Clarke正則な集合 $\Omega \subset \mathbb{R}^{n} ， \Omega$ において局所Lipschitz連続である 目的関数 $f: \mathbb{R}^{n} \rightarrow \mathbb{R}$ に対して, 問題

$$
\underset{\mathbf{x}}{\operatorname{minimize}} f(\mathbf{x}), \quad \text { s.t. } \mathbf{x} \in \Omega \text {, }
$$

の最適性条件 (一次の必要条件) は, Clarke-Jahn一般化方向微分係 数 $f^{\circ}(\mathbf{x} ; \mathbf{d})$ および接錐 $T_{\Omega}(\mathbf{x})$ を用いて

$$
f^{\circ}(\mathbf{x} ; \mathbf{d}) \geq 0, \quad \forall \mathbf{d} \in T_{\Omega}(\mathbf{x}),
$$

と表せる。(C4)は非平滑最適化問題における最適性条件である.

\section{Appendix D：最適性条件を満たす点への収束性の保証}

Algorithm 1により生成される探索点の点列を $\left\{\mathbf{x}^{k}\right\}$, 探索方向の ベクトル列を $\left\{\mathbf{d}^{k} \in D_{k}\right\}$ とする. 仮定2の下で「十分な降下条件」を 考慮することにより

- refining subsequence : $\lim _{k \in \mathcal{K}} \Delta_{k}=0$ かつ $\lim _{k \in \mathcal{K}} \mathbf{x}^{k}=\hat{\mathbf{x}}$ となるよ うな $\left\{\mathbf{x}^{k}\right\}$ の部分列 $\left\{\mathbf{x}^{k}\right\}_{k \in \mathcal{K}}$

- refining direction : 探索方向ベクトルの極限 $\mathbf{d}=\lim _{k \in \mathcal{L}} \mathbf{d}^{k} /\left\|\mathbf{d}^{k}\right\|$ が生成される ${ }^{8) 9)}$. ここで, $\mathcal{L} \subset \mathcal{K} \subset \mathbb{N}$ は無限列とし， $\mathcal{L}$ にいて は, ベクトル列 $\left\{\mathbf{d}^{k} /\left\|\mathbf{d}^{k}\right\|\right\}_{k \in \mathcal{L}}$ に極限が存在し, かつ十分大きい $k \in \mathcal{L}$ に対して $\mathbf{x}^{k}+\Delta_{k} \mathbf{d}^{k} \in \Omega$ となるようなものとする。このとき，

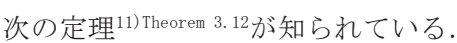

定理D1 : refining subsequenceの収束点 $\hat{\mathbf{x}}$ のまわりで目的関数 $f$ は 局所Lipschitz連続，集合 $\Omega$ は $\hat{\mathbf{x}}$ においてClarke正則とする。 $\mathbf{v} \in \operatorname{int} T_{\Omega}(\hat{\mathbf{x}})$ について $\mathbf{v} /\|\mathbf{v}\|$ がrefining directionならば， $\hat{\mathbf{x}}$ および $\mathbf{v}$ について次式が成り立つ.

$f^{\circ}(\hat{\mathbf{x}} ; \mathbf{v}) \geq 0$

よって, 最適性条件(C4)を満たすためには, すべての $\mathbf{v} \in \operatorname{int} T_{\Omega}(\hat{\mathbf{x}})$ がrefining directionとなる必要がある。次に,

条件D1：探索方向ベクトル $\left\{\mathbf{d}^{k} \in D_{k}\right\}_{k \in \mathcal{K}}$ は独立に生成され, 任意 の $\mathbf{v} \in T_{\Omega}(\hat{\mathbf{x}})$ および任意の $\varepsilon>0$ に対して次式が成り立つ.

$$
\sum_{k \in \mathcal{K}} \operatorname{Pr}\left(\left\|\mathbf{d}^{k} /\right\| \mathbf{d}^{k}\|-\mathbf{v} /\| \mathbf{v}\|\| \leq \varepsilon\right)=\infty
$$

を考える，条件D1を満たせば，Borel-Cantelliの補題例えば27)より

$$
\operatorname{Pr}\left(\mathbf{d}=\frac{\mathbf{v}}{\|\mathbf{v}\|}\right)=1
$$

となる $\mathbf{d}=\lim _{k \in \mathcal{L}} \mathbf{d}^{k} /\left\|\mathbf{d}^{k}\right\|$, および部分列 $\mathcal{L} \subset \mathcal{K}$ の存在が示せる. よって, 次の定理が導かれる。

定理D2：条件D1を満たせば，任意の $\mathbf{v} \in T_{\Omega}(\hat{\mathbf{x}})$ について, $\mathbf{v} /\|\mathbf{v}\|$ は確率1でrefining directionとなる。

定理D1および定理D2より，次の補題が導かれる.

補題 D1：条件 D1 を満たし, かつ int $T_{\Omega}(\hat{\mathbf{x}}) \neq \varnothing$ であれば, Algorithm 1により生成されるrefining subsequenceの収束点 $\hat{\mathbf{x}}$ にお いて最適性条件(C4)が確率1で満たされる.

2.3節の(7)のように探索方向ベクトル集合 $D_{k}$ の要素 $\mathbf{d}^{k}$ を生成した 場合，任意の $\mathbf{v} \in C_{\Omega}\left(\mathbf{x}^{k}, \Delta_{k}\right)$, 任意の $\varepsilon>0$, 十分大きい $k \in \mathcal{K}$ に対 して

$$
\operatorname{Pr}\left(\left\|\mathbf{d}^{k} /\right\| \mathbf{d}^{k}\|-\mathbf{v} /\| \mathbf{v} \| \leq \leq \varepsilon\right) \geq \delta, \quad \mathbf{d}^{k} \in D_{k}
$$

となる $\delta>0$ をとることができる。 $\varepsilon$-線形化錐 $C_{\Omega}(\mathbf{x}, \varepsilon)$ と接錐 $T_{\Omega}(\mathbf{x})$ との間には関係

$$
T_{\Omega}(\mathbf{x}) \subset C_{\Omega}(\mathbf{x}, 0)
$$

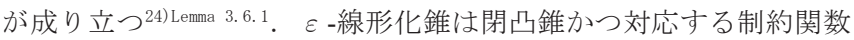
は連続微分可能であるので, $\lim _{k \in \mathcal{K}} \Delta_{k}=0$ および $\lim _{k \in \mathcal{K}} \mathbf{x}^{k}=\hat{\mathbf{x}}$ で あることに注意すれば,

$$
T_{\Omega}(\hat{\mathbf{x}}) \subset \lim _{k \in \mathcal{K}} C_{\Omega}\left(\mathbf{x}^{k}, \Delta_{k}\right)
$$

が言える.よって，任意の $\mathbf{v} \in T_{\Omega}(\hat{\mathbf{x}})$ ，任意の $\varepsilon>0$ に対して

$$
\sum_{k \in \mathcal{K}} \operatorname{Pr}\left(\left\|\mathbf{d}^{k} /\right\| \mathbf{d}^{k}\|-\mathbf{v} /\| \mathbf{v}\|\| \leq \varepsilon\right)=\infty, \quad \mathbf{d}^{k} \in D_{k}
$$

が成り立ち, 条件D1を満たす。よって, 補題D1により最適性条件 を満たす点へ確率1で収束することが保証される.

（2012年 6 月 9 日原稿受理，2012年 9 月18日採用決定） 